\title{
Inhibition of Carbonic Anhydrase by Parathyroid Hormone and Cyclic AMP in Rat Renal Cortex In Vitro
}

\author{
Nama Beck, Kwang Sup Kim, Margaret Wolak, and Bernard B. Davis \\ with the technical assistance of David H. Donald \\ From the Department of Medicine, Veterans Administration Hospital, University \\ of Pittsburgh School of Medicine, Pittsburgh, Pennsylvania 15240
}

\begin{abstract}
A в S T RACT It has been demonstrated that parathyroid hormone (PTH) inhibits the proximal tubular reabsorption of bicarbonate, and increases the urinary excretion of that ion. There is also a qualitative similarity between the alterations of the proximal tubular reabsorption of phosphate, sodium, and water after $\mathrm{PTH}$ administration and after acetazolamide administration. These findings suggest that the renal effect of PTH is possibly mediated through the inhibition of carbonic anhydrase in proximal tubules. Therefore, a possible inhibitory effect of $\mathrm{PTH}$ on carbonic anhydrase was evaluated in the homogenate of rat renal cortex by an indicator titration method.

Incubation of cortical homogenates with $\mathrm{PTH}$ for $10 \mathrm{~min}$ at $37^{\circ} \mathrm{C}$ inhibited carbonic anhydrase activity. The inhibitory effect of PTH was ATP-, $\mathrm{Mg}^{++}-$, and $\mathrm{K}^{+}$-dependent and temperature-dependent; inactivation of $\mathrm{PTH}$ by heating at $100^{\circ} \mathrm{C}$ abolished the effect of PTH both to activate adenylate cyclase and to inhibit carbonic anhydrase. Calcium $5 \mathrm{mM}$ also partially abolished effects of PTH to activate adenylate cyclase and to inhibit carbonic anhydrase. The inhibitory effect of $\mathrm{PTH}$ on carbonic anhydrase was specific to renal cortex.
\end{abstract}

Cyclic AMP, the intracellular messenger substance for $\mathrm{PTH}$, also inhibited carbonic anhydrase in renal cortex. The cyclic AMP-induced inhibition was also $\mathrm{Mg}^{++}$dependent and temperature dependent, and required preincubation at $37^{\circ} \mathrm{C}$. But $5^{\prime}$-AMP, a metabolic derivative of cyclic AMP without its biological effect, had no inhibitory effect on carbonic anhydrase.

All the above results are consistent with the hypothesis that PTH inhibits proximal tubular reabsorption of bicarbonate and phosphate through the inhibition of Received for publication 14 December 1973 and in revised
form 6 June 1974 . carbonic anhydrase, and that inhibitory effect is mediated through the cyclic AMP system.

\section{INTRODUCTION}

Hellman, Au, and Bartter (1) and other investigators (2-8) observed that parathyroid hormone $(\mathrm{PTH})^{1}$ increases the renal excretion of bicarbonate as well as phosphate, sodium, and water. Those investigators (1) postulated that the increased excretion of bicarbonate occurs via the inhibition of its reabsorption in the proximal tubule. This postulation is supported by the data of Agus and co-workers $(6,7)$ in micropuncture experiments that both $\mathrm{PTH}$ and its cellular messenger, cyclic AMP, inhibit proximal tubular reabsorption of phosphate, sodium, and water. Inhibition of carbonic anhydrase by pharmacological agents, such as acetazolamide, also inhibits proximal tubular reabsorption of phosphate, sodium, and water $(8-11)$ as well as bicarbonate (12-17). The qualitative similarity between the inhibition of proximal tubular reabsorption of those ions after the PTH administration and that after the inhibition of carbonic anhydrase by acetazolamide suggests that at least a part of renal effect of PTH is mediated through the inhibition of carbonic anhydrase in proximal tubules.

Puschett and Goldberg (8) and Beck and Goldberg (17) proposed that inhibition of proximal tubular reabsorption of bicarbonate increases luminal $\mathrm{pH}$, and decreases the ratio of $\mathrm{H}_{2} \mathrm{PO}_{4}^{-}$vs. $\mathrm{HPO}_{4}=$. Since $\mathrm{HPO}_{4}=$ is less diffusable across the tubular membrance than $\mathrm{H}_{2} \mathrm{PO}_{4}$, the increase of luminal $\mathrm{pH}$ consequently reduces the net reabsorption of phosphate. Then, it is reasonable to postulate that the phosphaturic effect of

\footnotetext{
${ }^{1}$ Abbreviation used in this paper: $\mathrm{PTH}$, parathyroid hormone.
} 
TABLE I

Effect of Various Study Substances on the Assay System of Carbonic Anhydrase

\begin{tabular}{|c|c|c|}
\hline Substances & $n$ & $\begin{array}{l}\text { Reaction } \\
\text { time }\end{array}$ \\
\hline & & $s$ \\
\hline Control $\mathrm{H}_{2} \mathrm{O}$ & 6 & $110.8 \pm 0.7$ \\
\hline $0.1 \mathrm{mM}$ ATP, $1.6 \mathrm{mM} \mathrm{Mg}^{++}$, and $25 \mathrm{mM} \mathrm{K}^{+}$ & 6 & $113.3 \pm 0.9$ \\
\hline PTH $10 \mathrm{U} / \mathrm{ml}, \mathrm{ATP}, \mathrm{Mg}^{++}$, and $\mathrm{K}^{+}$ & 6 & $109.3 \pm 0.8$ \\
\hline Cyclic AMP $0.4 \mathrm{mM}, \mathrm{ATP}, \mathrm{Mg}^{++}$, and $\mathrm{K}^{+}$ & 6 & $110.8 \pm 0.8$ \\
\hline
\end{tabular}

Values are means and SE. $P>0.05$ among four groups.

PTH might also be mediated through the inhibition of carbonic anhydrase and an alteration of luminal $\mathrm{pH}$. The microperfusion data of Bank, Aynedjian, and Weinstein (18) are consistent with this postulate in showing that $\mathrm{PTH}$ inhibits $\mathrm{H}_{2} \mathrm{PO}_{4}^{-}$transport in proximal tubules, but that hormone has no demonstrable effect on $\mathrm{HPO}_{4}=$ transport. All the above findings (1-18) support the hypothesis that PTH inhibits proximal tubular reabsorption of bicarbonate and $\mathrm{H}_{2} \mathrm{PO}_{4}^{-}$transport via the inhibition of carbonic anhydrase and the alteration of luminal $\mathrm{pH}$. This hypothesis was evaluated in this series of experiments by measuring the effect of PTH and cyclic AMP, intracellular messenger of PTH, on carbonic anhydrase activity in renal cortex.

\section{METHODS}

Measurements of carbonic anhydrase activity. Maren's micro phenol red indicator method (19) was adapted for this experiment. The substrate buffer was $250 \mu \mathrm{l} /$ tube of a mixture containing $296 \mathrm{mM} \mathrm{Na} \mathrm{CO}_{3}$ and $204 \mathrm{mM} \mathrm{NaHCO}$; the flow rate of $100 \% \mathrm{CO}_{2}$ was $400 \pm \mathrm{SD} 8 \mathrm{ml} / \mathrm{min}$; the concentration of phenol red indicator was $1 \mu \mathrm{g} / \mathrm{ml}$-tube. This assay system yielded $120 \mathrm{~s}$ of noncatalytic reaction time. This reaction time produced greater precision and reproducibility in the experiments as compared to the $40 \mathrm{~s}$ noncatalytic reaction time used in Maren's original method. During the procedure, specimens were kept at $1.0 \pm 1.0^{\circ} \mathrm{C}$ by using an Aminco constant flow-through cold water bath (American Instrument Co., Inc., Silver Spring, Md.). The actual $\mathrm{pH}$ at the end point of phenol red indicator was measured by a Radiometer $\mathrm{pH}$ meter (Radiometer Co., Copenhagen, Denmark), and it was 7.2 \pm SD 0.2. The enzyme activity which halves the noncatalytic reaction time under the specified conditions was defined as one unit of carbonic anhydrase activity as described by Maren, Ash, and Bailey $(19,20)$. To evaluate the effect of phenol red indicator on enzyme activity and the precision of the indicator method (21), the enzyme activity of the principle experiments was measured by both the indicator method and an electrometric method without indicator. The results of those two methods were similar, indicating no measurable effect of phenol red on the assay system. The various study substances did not induce any measurable differences in diffusability and solubility of $\mathrm{CO}_{2}$ gas, and those substances did not induce any measurable effect on the carbonic anhydrase assay (Table I). A control group, enzyme without study substance, was included in each series of experiments as an internal standard. The study mixture was composed of 250 $\mu 1$ buffer, $500 \mu 1$ study substances, and $250 \mu 1$ carbonic anhydrase per tube.

Carbonic anhydrase inhibition. Sprague-Dawley rats weighing $200-250 \mathrm{~g}$ were anesthetized with $7 \mathrm{mg}$ of sodium pentobarbital, and $60 \mathrm{ml}$ of $150 \mathrm{mM} \mathrm{NaCl}$ was infused through the renal arteries in less than $15 \mathrm{~s}$ to remove the erythrocytes from the kidney tissue. Renal cortex was separated from the medulla and was homogenized in ice cold glass-distilled water using a Sorvall tissue grinder (Ivan Sorvall, Inc., Newtown, Conn.). The homogenate was then filtered through Whatman filter paper no. 2. Thorough removal of erythrocyte in the renal cortical homogenate was checked by the guaiac test. Hereafter, unless specified, carbonic anhydrase refers to the enzyme prepared from renal cortex. The carbonic anhydrase activity had a linear relationship with the enzyme concentration in the range of 0.05-1.5 U/tube. Therefore, in subsequent experiments, the basal activity of carbonic anhydrase was always maintained at about $1 \mathrm{U} /$ tube, $70-100 \mu \mathrm{g}$ protein/tube. Carbonic anhydrase from gastric mucosa and erythrocytes was also suspended in glass-distilled water, and each of the enzyme preparations was titrated to yield enzyme activity comparable to that of renal cortex.

Carbonic anhydrase activities were assayed by the following procedure. Study substances, $500 \mu \mathrm{l} /$ tube, were mixed with $250 \mu 1$ of carbonic anhydrase preparation suspended in glass-distilled water. After variable lengths of incubation at variable temperatures, as described in the Results, the tubes were cooled to $1^{\circ} \mathrm{C}$ in the cold water bath. Then, $250 \mu 1$ of substrate buffer was added, and the sample was bubbled with $\mathrm{CO}_{2}$ gas.

The methods to measure adenylate cyclase activity and phosphodiesterase activity have been described previously in detail (22). Protein concentration was measured by the method of Lowry, Rosebrough, Farr, and Randall (23).

PTH and cyclic AMP solutions, and carbonic anhydrase mixture were adjusted to $\mathrm{pH} 4.5$ and 7.0 , respectively, using $\mathrm{HCl}$ and $\mathrm{NaOH}$ in order to evaluate the effect of $\mathrm{pH}$ on carbonic anhydrase. Since PTH and cyclic AMP solutions do not contain buffer, an extreme caution was needed in adjusting $\mathrm{pH}$. Then, the mixture of carbonic anhydrase

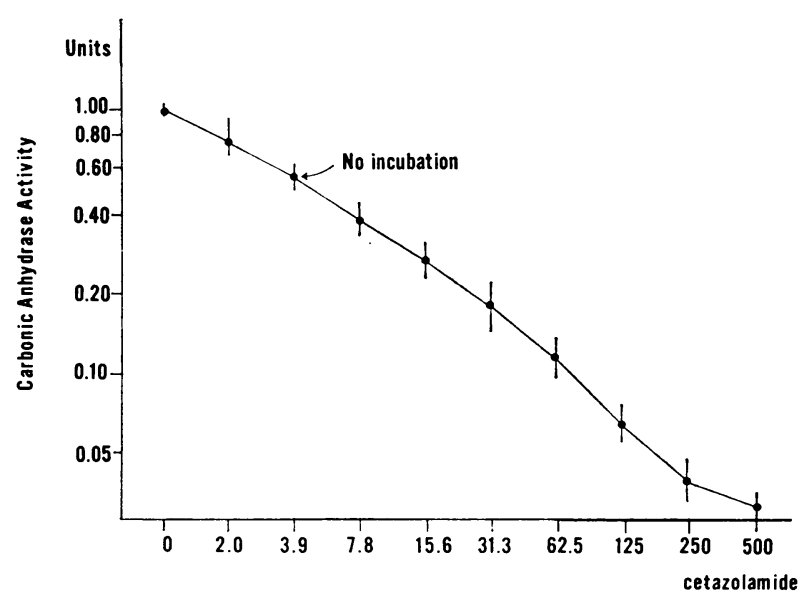

FIGURE 1 Inhibition of carbonic anhydrase by increasing concentrations of acetazolamide. Each value is mean and $\mathrm{SE}$ of six determinations. 
alone (control), and the mixture with the addition of either PTH or cyclic AMP were preincubated for $10 \mathrm{~min}$ at $37^{\circ} \mathrm{C}$ as shown in Table V. Then carbonic anhydrase activity was determined.

To evaluate the reversibility of the inhibition of carbonic anhydrase by cyclic AMP, the carbonic anhydrase mixture was preincubated for $10 \mathrm{~min}$ at $37^{\circ} \mathrm{C}$ without cyclic AMP for the control group, and with $0.2 \mathrm{mM}$ cyclic AMP for the cyclic AMP groups. After $24 \mathrm{~h}$ dialysis at $4^{\circ} \mathrm{C}$ against distilled water or against $0.2 \mathrm{mM}$ cyclic AMP as shown in the Results, carbonic anhydrase activity was assayed.

Synthetic amino-terminal 1-34-PTH was obtained from the Beckman Instrument Inc. (Palo Alto, Calif.), and cyclic AMP, ATP, and anhydrous acetazolamide from the Sigma Chemical Co. (St. Louis, Mo.).

\section{RESULTS}

There was a logarithmic relationship between the concentration of acetazolamide and its inhibitory effect on carbonic anhydrase activity (Fig. 1). 2 nM acetazolamide, the lowest concentration used in this experiment, inhibited carbonic anhydrase from 1.08 \pm SE $0.01 \mathrm{U}$ in the control to $0.80 \pm 0.05 \mathrm{U}$, and $500 \mathrm{nM}$ inhibited to $0.03 \pm 0.03 \mathrm{U}$.

Incubation of the enzyme mixture with $7.8 \mathrm{nM}$ acetazolamide for $10 \mathrm{~min}$ at $37^{\circ} \mathrm{C}$ did not measurably increase the inhibitory effect of acetazolamide: $0.42 \pm 0.02$ $\mathrm{U}$ without incubation vs. $0.35 \pm 0.03 \mathrm{U}$ after incubation, $P>0.05$. However, the inhibitory effect of PTH 10 $\mathrm{U} / \mathrm{ml}$ on carbonic anhydrase was demonstrable only after $10 \mathrm{~min}$ incubation at $37^{\circ} \mathrm{C}$ with $0.1 \mathrm{mM}$ ATP, 1.6 $\mathrm{mM} \mathrm{MgCl}, 25 \mathrm{mM} \mathrm{KCl}$ (Figure 2). The inhibitory effect of PTH on carbonic anhydrase was much less or not demonstrable: (a) without $10 \mathrm{~min}$ incubation, (b) with incubation at $1^{\circ} \mathrm{C}$ instead of $37^{\circ} \mathrm{C}$ for $10 \mathrm{~min}$, (c) with $\mathrm{PTH}$ but without $\mathrm{ATP}, \mathrm{Mg}^{++}$, and $\mathrm{K}^{+}$, or (d) with $\mathrm{PTH}$ inactivated by heating in a boiling water bath for $3 \mathrm{~min}$ (Table II). There was a dose-

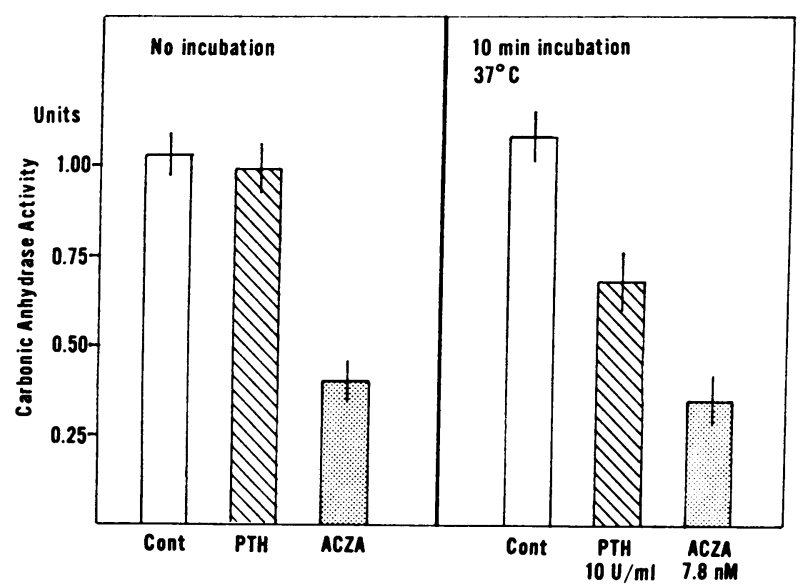

FIGURE 2 Comparison of the inhibitory effect of PTH $10 \mathrm{U} / \mathrm{ml}$ and acetazolamide (ACZA) $7.8 \mathrm{nM}$. Values are means and $\mathrm{SE}$ of eight determinations.
TABLE II

Effects of PTH on Carbonic Anhydrase and Adenylate Cyclase of Rat Renal Cortex

\begin{tabular}{lcc}
\hline & $\begin{array}{c}\text { Carbonic } \\
\text { anhydrase }\end{array}$ & $\begin{array}{c}\text { Adenylate } \\
\text { cyclase }\end{array}$ \\
\hline & $U$ & $\begin{array}{c}\text { pmol } / \mathrm{mg} \\
\text { protein-min }\end{array}$ \\
Control & $1.01 \pm 0.01$ & $7.5 \pm 0.1$ \\
PTH $10 \mathrm{U} / \mathrm{ml}$, incubated for $10 \mathrm{~min}$ at $37^{\circ} \mathrm{C}$ & $0.70 \pm 0.01 *$ & $19.5 \pm 0.3^{*}$ \\
PTH $10 \mathrm{U} / \mathrm{ml}$, without incubation & $0.93 \pm 0.02$ & \\
PTH $10 \mathrm{U} / \mathrm{ml}$, incubated for $10 \mathrm{~min}$ at $1^{\circ} \mathrm{C}$ & $0.95 \pm 0.02$ & $7.5 \pm 0.2$ \\
PTH $10 \mathrm{U} / \mathrm{ml}$, without ATP, $\mathrm{Mg}^{+}$, or $\mathrm{K}^{+}$ & $0.94 \pm 0.01$ & \\
PTH inactivated by heating & $0.94 \pm 0.01$ & $10.1 \pm 0.2^{*}$ \\
\hline
\end{tabular}

Unless otherwise specified, incubation was with $0.1 \mathrm{mM}$ ATP, $1.6 \mathrm{mM}$ $\mathrm{Mg}^{++}$, and $25 \mathrm{mM} \mathrm{K}$. Values are means and $\mathrm{SE}$ of eight determinations for carbonic anhydrase and 10 determinations for adenylate cyclase.

* $P<0.01$ as compared to the corresponding control value.

inhibition relationship between $\mathrm{PTH}$ concentrations, 5-100 U/ml, and carbonic anhydrase activity (Fig. 3).

In a carbonic anhydrase mixture prepared identically to that used in the above experiments with $\mathrm{PTH}$, the basal adenylate cyclase activity was augmented by $\mathrm{PTH}$ $10 \mathrm{U} / \mathrm{ml}$ in the presence of $0.1 \mathrm{mM} \mathrm{ATP}, 1.6 \mathrm{mM}$ $\mathrm{Mg}^{++}$, and $25 \mathrm{mM} \mathrm{K}^{+}$. Cyclic AMP concentration was increased from $10.0 \pm 0.1 \mathrm{nM}$ to $26.2 \pm 0.4$, but there was no measurable augmentation of the enzyme activity with an incubation at $1^{\circ} \mathrm{C}$, and much less augmentation by the inactivated PTH (Table II). In the same preparation, cyclic AMP-phosphodiesterase activity was 2.07 $\mu \mathrm{mol}$ hydrolysis $/ \mathrm{min}$ in the presence of $0.2 \mathrm{mM}$ cyclic AMP.

The carbonic anhydrase activity, $1.02 \pm 0.01 \mathrm{U}$, was not affected by $5 \mathrm{mM}$ calcium alone, $1.04 \pm 0.01 \mathrm{U}$, $P>0.05$. But the inhibition of carbonic anhydrase to $0.70 \pm 0.01 \mathrm{U}$ by $\mathrm{PTH} 10 \mathrm{U} / \mathrm{ml}$ was partially abolished to $0.93 \pm 0.01$ by $5 \mathrm{mM}$ calcium, $P<0.05$ (Figure 4 ).

Other hormones which act on the kidney through the cyclic AMP system, i.e., vasopressin, isoproterenol, or prostaglandin $E_{1}$, had no measurable effect on carbonic anhydrase prepared from renal cortex (Table III). The inhibitory effect of PTH $10 \mathrm{U} / \mathrm{ml}$ on carbonic anhydrase was demonstrable only in renal cortical homogenate, but not in homogenates of renal medulla, erythrocytes, or gastric mucosa (Table IV).

The incubation with cyclic AMP at $37^{\circ} \mathrm{C}$ inhibited carbonic anhydrase in a dose-inhibition (Fig. 5) and in a progressive time-dependent fashion (Fig. 6) from the basal activity of $1.06 \pm 0.04 \mathrm{U}$ to $0.24 \pm 0.06 \mathrm{U}$ after $20 \mathrm{~min}$ incubation. However, the inhibitory effect of cyclic AMP was not demonstrable in the absence of $\mathrm{Mg}^{++}, 0.99 \pm 0.02$; without incubation, $0.99 \pm 0.03 \mathrm{U}$; or with $20 \mathrm{~min}$ incubation at $1^{\circ} \mathrm{C}$ instead of $37^{\circ} \mathrm{C}, 100$ $\pm 0.01, P>0.05$. In contrast to the anatomical speci- 


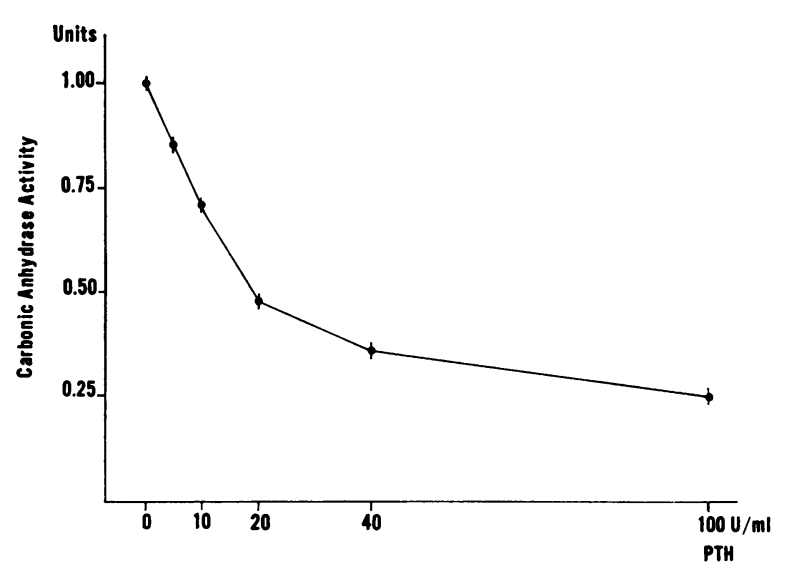

FIgURE 3 Dose-inhibition of carbonic anhydrase by increasing concentrations of PTH. Each value is mean and $\mathrm{SE}$ of eight determinations. The enzyme mixture containing 0.1 $\mathrm{mM} \mathrm{ATP}, 1.6 \mathrm{mM} \mathrm{Mg}^{++}$, and $25 \mathrm{mM} \mathrm{K} \mathrm{K}^{+}$were incubated for $10 \mathrm{~min}$ at $37^{\circ} \mathrm{C}$.

ficity of PTH to renal cortex, $0.2 \mathrm{mM}$ cyclic AMP inhibited carbonic anhydrase in renal medulla and erythrocytes, as well as that in renal cortex (Table IV).

$\mathrm{pH}$ of the homogenate of renal cortex was $4.8 \pm 0.1$ in the presence of $\mathrm{PTH} 10 \mathrm{U} / \mathrm{ml}$, and $\mathrm{pH} 4.5-5.2$ with cyclic AMP. When $\mathrm{pH}$ of cortical homogenates had been adjusted to 4.5 or 7 by $\mathrm{HCl}$ or $\mathrm{NaOH}$, and then incubated for $10 \mathrm{~min}$ at $37^{\circ} \mathrm{C}$, there was no measurable difference in carbonic anhydrase activities between the $\mathrm{pH} 4.5$ group and the $\mathrm{pH} 7.0$ group, $P>0.05$ (Table V). PTH and cyclic AMP solutions of both $\mathrm{pH} \quad 4.5$ and 7.0 significantly inhibited carbonic anhydrase, $P<0.01$ (Table V). However, the inhibitory effect of cyclic AMP on carbonic anhydrase was significantly less in the $\mathrm{pH} 7.0$ group than in the $\mathrm{pH} 4.5$ group, $P<0.01$.

In the control group, dialysis alone against $0.2 \mathrm{mM}$ cyclic AMP at $4^{\circ} \mathrm{C}$ in the absence of magnesium in the dialysate, had very little effect on carbonic anhydrase activity as compared to dialysis against distilled water (Table VI). However, after carbonic anhydrase had been inhibited by preincubation at $37^{\circ} \mathrm{C}$ with $0.2 \mathrm{mM}$ cyclic AMP and $1.6 \mathrm{mM}$ magnesium, the enzyme activity was much greater in the group dialyzed against distilled water than in the group dialyzed against cyclic AMP, $P<0.01$, suggesting a partial restoration of the enzyme activity by the dialysis against water.

\section{DISCUSSION}

There are several methods to measure carbonic anhydrase activity, each subject to certain critcisms (21). Because of its simplicity, indicator methods have been widely used. In the present experiments, the principle of Maren's method was used with some modifications to improve the precision and reproducibility. The validity of this assay system (21) was carefully evaluated as described in the Methods section.

The dose-inhibition relationship between the concentration of acetazolamide and the inhibition of carbonic anhydrase in the present assay system shown in Fig. 1 is comparable to the data of other investigators (19, 20, 24-26).

PTH inhibited carbonic anhydrase only after $10 \mathrm{~min}$ preincubation at $37^{\circ} \mathrm{C}$ in the presence of $\mathrm{ATP}, \mathrm{Mg}^{++}$, and $\mathrm{K}^{+}$, with a dose-inhibition relationship between $\mathrm{PTH} \quad 5-100 \mathrm{U} / \mathrm{ml}$ and carbonic anhydrase activity (Fig. 3). However, with a submaximal concentration of $7.8 \mathrm{nM}$ acetazolamide, which inhibits $60 \%$ of carbonic anhydrase activity, $10 \mathrm{~min}$ preincubation at $37^{\circ} \mathrm{C}$ did not augment the inhibitory effect of acetazolamide. The $\mathrm{Mg}^{++}$dependency and the need for incubation to inhibit carbonic anhydrase suggest that PTH is probably not a direct inhibitor of carbonic anhydrase, but rather that $\mathrm{PTH}$ initiates certain biochemical reactions, and those reactions may subsequently inhibit carbonic anhydrase. Since the renal effects of PTH $(22,27,28)$ are mediated through the cyclic AMP system, it is reasonable to postulate that the inhibitory effect of PTH on carbonic anhydrase may also be mediated through the cyclic AMP system. This postulation is supported by the following findings: $(a)$ in the homogenate of renal cortex, PTH inhibits carbonic anhydrase, and the same hormone activates adenylate cyclase (Table II) ; (b) both the inhibition of carbonic anhydrase and the activation of adenylate cyclase induced by $\mathrm{PTH}$ were time and temperature dependent; (c) ATP,

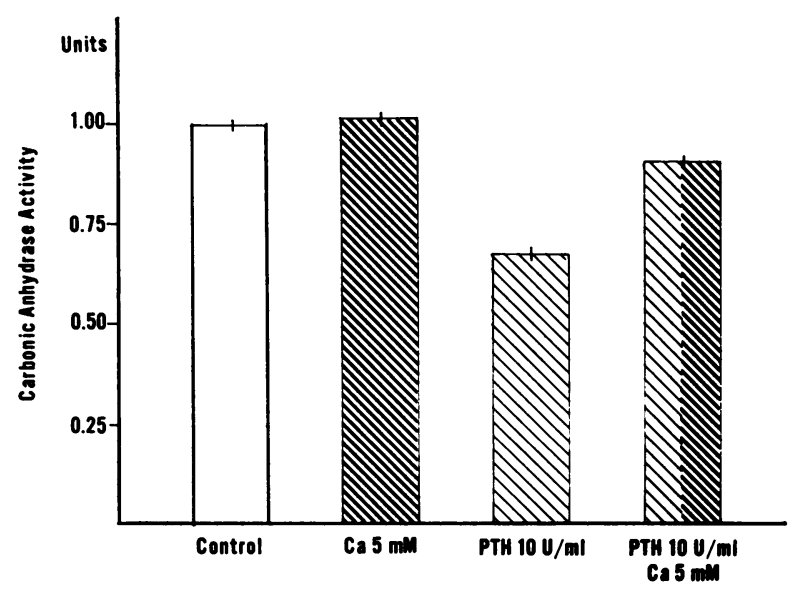

FI:URE 4 Interaction between calcium and PTH. The enzyme mixtures with $0.1 \mathrm{mM}$ ATP, $1.6 \mathrm{mM} \mathrm{Mg} \mathrm{Mg}^{++}$, and 25 $\mathrm{mM} \mathrm{K} \mathrm{K}^{+}$, and the study substances as shown in the abscissa were incubated for $10 \mathrm{~min}$ at $37^{\circ} \mathrm{C}$. Each bar is mean and $\mathrm{SE}$ of eight determinations. 
$\mathrm{Mg}^{++}$, and $\mathrm{K}^{+}$were necessary for both the inhibition of carbonic anhydrase and the activation of adenylate cyclase by $\mathrm{PTH}(22)$; $(d)$ heating of $\mathrm{PTH}$ to $100^{\circ} \mathrm{C}$ abolished the effect of the hormone both to inhibit carbonic anhydrase and to activate adenylate cyclase; (e) high calcium concentration, which inhibits the phosphaturic effect of $\mathrm{PTH}$ through the inhibition of PTH-dependent adenylate cyclase in renal cortex (22), also diminished the inhibitory effect of PTH on carbonic anhydrase; $(f)$ the inhibitory effect on carbonic anhydrase was hormonally specific to $\mathrm{PTH}$. Other hormones acting in the kidney, such as vasopressin (29), catecholamine (30), or prostaglandin $E_{1}$ (29), had no measurable inhibitory effect on carbonic anhydrase; $(g)$ the inhibitory effect of PTH on carbonic anhydrase was also specific to renal cortex, and PTH had no measurable effect on carbonic anhydrase prepared from renal medulla, gastric mucosa, or erythrocyte. The hormonal and tissue specificities of the carbonic anhydrase system are similar to those of the PTH-dependent cyclic AMP system in the kidney. However, cyclic AMP, the intracellular messenger of PTH and of many other hormones (27), did not demonstrate the anatomical specificity. Even though these experiments were in the in vitro system, all the above findings are consistent with the hypothesis that PTH inhibits carbonic anhydrase in renal cortex through the cyclic AMP system, and suggest that the inhibition of carbonic anhydrase is due to a physiological effect rather than a nonspecific toxic effect of PTH.

Cyclic AMP per se does not appear to be a direct inhibitor of carbonic anhydrase, since that nucleotide also requires $\mathrm{Mg}^{++}$and an incubation at $37^{\circ} \mathrm{C}$ to inhibit the enzyme activity. The lack of inhibition with

TABLE III

Effects of Various Hormones on Renal Cortical Carbonic Anhydrase

\begin{tabular}{lcc}
\hline \multicolumn{1}{c}{ Substances } & $n$ & $\begin{array}{c}\text { Carbonic anhydrase } \\
\text { activity }\end{array}$ \\
\hline Control & 8 & $\begin{array}{c}U \\
\text { PTH } 10 \mathrm{U} / \mathrm{ml}\end{array}$ \\
Vasopressin $10 \mathrm{mU} / \mathrm{ml}$ & 8 & $0.18 \pm 0.01$ \\
Isoproterenol $1 \mu \mathrm{M}$ & 8 & $1.11 \pm 0.03^{*}$ \\
Prostaglandin $\mathrm{E}_{1} 1 \mu \mathrm{M}$ & 8 & $1.12 \pm 0.02$ \\
\hline
\end{tabular}

The enzyme preparations were incubated with the study substances for $10 \mathrm{~min}$ at $37^{\circ} \mathrm{C}$, and the enzyme activity was measured after cooling the specimen to $1^{\circ} \mathrm{C}$. Values are means and SE.

${ }^{*} P<0.01$ as compared to the control value.
TABLE IV

Effect of PTH and Cyclic AMP on Carbonic Anhydrase in Various Tissues

\begin{tabular}{lcccc}
\hline & $n$ & Basal & PTH $10 \mathrm{U} / \mathrm{ml}$ & $\begin{array}{c}\text { Cyclic AMP } \\
0.2 \mathrm{mM}\end{array}$ \\
\hline Renal cortex & 8 & $1.01 \pm 0.01$ & $0.70 \pm 0.01^{*}$ & $0.24 \pm 0.06^{*}$ \\
Renal medulla & 6 & $1.02 \pm 0.02$ & $0.98 \pm 0.01$ & $0.69 \pm 0.01^{*}$ \\
Erythrocytes & 6 & $0.95 \pm 0.03$ & $0.91 \pm 0.03$ & $0.75 \pm 0.01^{*}$ \\
\hline
\end{tabular}

Carbonic anhydrase preparations were preincubated for $10 \mathrm{~min}$ at $37^{\circ} \mathrm{C}$ without study substance (basal), PTH $10 \mathrm{U} / \mathrm{ml}$, or cyclic AMP $0.02 \mathrm{mM}$. Values are means and $\mathrm{SE}$. ${ }^{*} P<0.01$ as compared to the corresponding basal value.

$5^{\prime}$-AMP, which is a metabolic derivative of cyclic AMP without its biological effect (22), further suggests that the inhibitory effect of cyclic AMP on carbonic anhydrase is related to the biological effect of the nucleotide.

The minimal concentration of $\mathrm{PTH}$ to inhibit carbonic anhydrase was $5 \mathrm{U} / \mathrm{ml}$, and $50 \%$ inhibition of the activity was seen with $20 \mathrm{U} / \mathrm{ml}$. This may appear to be a high concentration of $\mathrm{PTH}$ as compared to the plasma concentration of PTH (31). However, an optimal concentration of the hormone in an in vitro system is not directly comparable to that of in vivo. In the broken-cell preparation of renal cortex, Marcus and Aurbach (32) reported a minimal activation of adenylate cyclase with $\mathrm{PTH} 4 \mathrm{U} / \mathrm{ml}$, and a maximal activation with $\mathrm{PTH} 100 \mathrm{U} / \mathrm{ml}$, a range of concentration similar to our results (Fig. 3 ).

The minimal concentration of cyclic AMP to inhibit carbonic anhydrase was $0.2 \mathrm{mM}$ in the present in vitro system. This value is higher than the measured cyclic AMP concentration, $0.05 \mathrm{mM}$, in the isolated renal tubular cells (33), and the measured value, $26.2 \mathrm{nM}$, in the mixture of carbonic anhydrase after $10 \mathrm{~min}$ incubation with $\mathrm{PTH}$ in the present experiments. Here again, it should be emphasized that the optimal concentration of cyclic AMP in an in vitro system is not directly comparable to that in vivo. Furthermore, the measured concentration of cyclic AMP in the mixture of carbonic anhydrase after the incubation with PTH and the concentration of an exogenous cyclic AMP cannot be quantitatively compared for their respective physiological effects. The measured cyclic AMP concentration in the PTH group is the one remaining after the incubation and after the hydrolysis by cyclic AMPphosphodiesterase in the enzyme mixture. But the concentration of cyclic AMP in the exogenous cyclic AMP group is the initial concentration added, and does not 


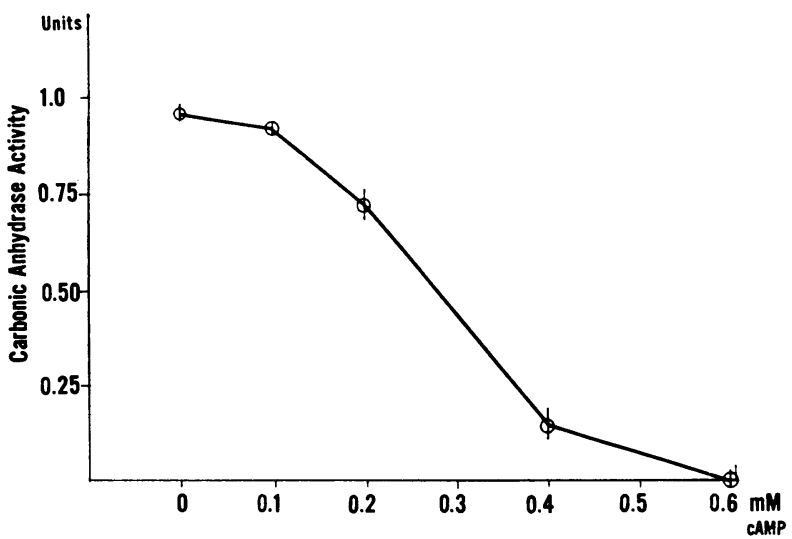

FIGURE 5 Dose-inhibition relationship between cyclic AMP (cAMP) concentrations and carbonic anhydrase activity. Renal cortical homogenate contained $1.6 \mathrm{mM} \mathrm{Mg}^{++}$and 25 $\mathrm{mM} \mathrm{K}$, and incubated for $2 \mathrm{~min}$ at $37^{\circ} \mathrm{C}$. Values are means and $\mathrm{SE}$ of eight determinations.

take into account the amount of cyclic AMP hydrolyzed during $10 \mathrm{~min}$ incubation. However, the lower concentration of cyclic AMP in the PTH group may in part explain a lesser inhibition of carbonic anhydrase by PTH than that by exogenous cyclic AMP.

Since cyclic AMP is a phosphoric acid, and since there is no buffer in the assay mixture of carbonic anhydrase, an addition of cyclic AMP or PTH lowered the $\mathrm{pH}$ of the carbonic anhydrase mixture to the range of 4.5 to 5.2. The acidic $\mathrm{pH}$, per se, may inhibit carbonic anhydrase. Therefore, the effect of variable $\mathrm{pH}$, per se, on carbonic anhydrase activity was investigated as shown in Table V. Lowering of $\mathrm{pH}$ from 7.0 to 4.5 had no measurable effect on the carbonic anhydrase activity, and furthermore, both PTH and cyclic AMP had an inhibitory effect on carbonic anhydrase both at $\mathrm{pH} 4.5$ and 7.0. These results suggest that the inhibitory effect of PTH or cyclic AMP on carbonic anhydrase is not due to the alteration of $\mathrm{pH}$ induced by those substances. The inhibitory effect of cyclic AMP on carbonic anhydrase was significantly less in the solution with $\mathrm{pH} 7.0$ than in that with $\mathrm{pH} 4.5$. Since cyclic AMP is a phosphoric acid, and since $\mathrm{pH}$ of cyclic AMP solution was adjusted in the absence of buffer, it is very conceivable that a part of cyclic AMP was chemically denatured by alkaline $\mathrm{pH}$ during the adjustment of $\mathrm{pH}$. Whatever mechanism is involved for the difference in the inhibitory effect of cyclic AMP between $\mathrm{pH} 4.5$ and $\mathrm{pH} 7.0$, the data in Table $\mathrm{V}$ clearly demonstrate that cyclic AMP inhibits carbonic anhydrase at $\mathrm{pH} 7.0$.

The findings that dialysis against distilled water partially restores carbonic anhydrase activity which had been inhibited by cyclic AMP suggest that at least a part of the inhibitory mechanism of cyclic AMP on carbonic anhydrase was reversible, and that reversibility further suggests that the inhibition was not due to denature of the enzyme by a nonspecific toxic effect of cyclic AMP.

Both PTH and cyclic AMP are natural physiological substances, and their inhibitory effect on carbonic anhydrase was $\mathrm{Mg}^{++}$, $\mathrm{K}^{+}$, and ATP-dependent, and temperature-dependent, and the biologically inactive derivatives, i.e. heated PTH and 5'AMP, did not inhibit the enzyme activity. Furthermore, there is no evidence in the system tested to indicate that the inhibitory effect of those substances on carbonic anhydrase is due to a nonspecific toxic effect. Those findings suggest that the inhibitory effect of PTH and cyclic AMP is probably a biological function of PTH and cyclic AMP.

Based on calculation of the inhibitory kinetics of acetazolamide in homogenates in vitro and the concentration of acetazolamide in the homogenate of renal cortex, Maren (34) postulated that more than $90 \%$ of carbonic anhydrase in the kidney (35) should be inhibited to induce a measurable increase of bicarbonate excretion. PTH is a natural physiological hormone; it induces multiple cascade reactions including the activation of the cyclic AMP system, and a final reaction of those intermediate reactions possibly involves inhibition of carbonic anhydrase. In contrast, acetazolamide is a pharmacological agent with a direct inhibitory effect on carbonic anhydrase. Therefore, the effect of PTH on carbonic anhydrase cannot be quantitatively compared to that of acetazolamide. However, cyclic AMP, which is the intracellular messenger for PTH, depends on less intermediate reactions than $\mathrm{PTH}$, and that can cause more than $90 \%$ inhibition of carbonic anhydrase. These findings are compatible with Maren's hypothesis (34).

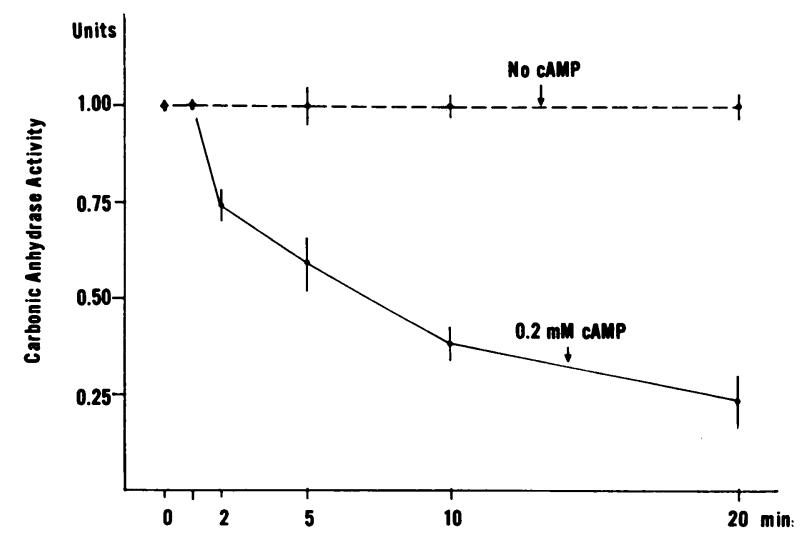

FIGURE 6 The relationship between the duration of incubation and the inhibition of carbonic anhydrase. The homogenate was incubated with $0.2 \mathrm{mM}$ cyclic AMP (cAMP), $1.6 \mathrm{mM} \mathrm{Mg}^{++}$, and $25 \mathrm{mM} \mathrm{K} \mathrm{K}^{+}$, and incubated at $37^{\circ} \mathrm{C}$. Values are means and $\mathrm{SE}$ of eight experiments. 
TABLE V

Effect of $p H$ on the Inhibitory Effect of PTH and Cyclic $A M P$

\begin{tabular}{lrcc}
\hline & $n$ & $\mathrm{pH} 4.5$ & $\mathrm{pH} 7.0$ \\
\hline & & $U$ & $U$ \\
Control & 10 & $1.03 \pm 0.04$ & $0.95 \pm 0.04$ \\
PTH 10 U/ml & 5 & $0.70 \pm 0.03^{*}$ & $0.64 \pm 0.01^{*}$ \\
Cyclic AMP 0.6 mM & 5 & $0.09 \pm 0.01^{*}$ & $0.25 \pm 0.01^{*}$ \\
\hline
\end{tabular}

The carbonic anhydrase activity after $10 \mathrm{~min}$ incubation at $37^{\circ} \mathrm{C}$. Values are means and SE.

${ }^{*} P<0.01$ as compared to the corresponding control values.

The attempts by Puschett and Goldberg (8) and other investigators (17) to demonstrate a direct inhibitory effect of PTH and cyclic AMP on carbonic anhydrase have not been successful. In their publications it is not clear whether they used the carbonic anhydrase prepared from renal cortex or erythrocytes. However, their observation is not inconsistent with the data in the present experiments: neither PTH nor cyclic AMP demonstrated any direct inhibitory effect on carbonic anhydrase unless the enzyme had been incubated with $\mathrm{PTH}$ or cyclic AMP and $\mathrm{Mg}^{++}$at $37^{\circ} \mathrm{C}$. Furthermore, since the inhibitory effect of $\mathrm{PTH}$ and cyclic AMP on carbonic anhydrase probably occurs through an induction of intermediate reactions during the incubation, those intermediate reactions may not occur in a purified preparation of carbonic anhydrase $(8,17)$.

The results in this experiment are consistent with the hypothesis that: (a) PTH inhibits carbonic anhydrase specifically in renal cortex in vitro, $(b)$ this inhibition is probably through the cyclic AMP system, (c) and the inhibition of proximal tubular reabsorption of bicarbonate, phosphate, sodium, and water after the administration of PTH or cyclic AMP (1-8) might be at least in part mediated through the inhibition of carbonic anhydrase.

\section{TABLE VI}

Effect of Dialysis on the Inhibition of Carbonic Anhydrase by Cyclic AMP

\begin{tabular}{lccc}
\hline & & \multicolumn{2}{c}{ Dialysis for $24 \mathrm{~h}$ at $4^{\circ} \mathrm{C}$ against } \\
\cline { 3 - 4 } $\begin{array}{c}\text { Preincubation for } \\
10 \text { min at } 37^{\circ} \mathrm{C}\end{array}$ & $n$ & Water & $\begin{array}{c}0.2 \mathrm{mM} \\
\text { cyclic AMP }\end{array}$ \\
\hline & & $U$ & $U$ \\
Control & 6 & $1.14 \pm 0.02$ & $1.01 \pm 0.02$ \\
Cyclic AMP $0.2 \mathrm{mM}$ & 6 & $0.60+0.02^{*}$ & $0.28 \pm 0.01^{*}$ \\
\hline
\end{tabular}

Values are means and SE.

${ }^{*} P<0.01$ between the two values.

\section{ACKNOWLEDGMENTS}

The authors thank Wono Lee for his editorial advice, and Ruth Greenlee and Marilyn Schuster for their assistance on preparation of this manuscript.

\section{REFERENCES}

1. Hellman, D. E., W. Y. W. Au, and F. C. Bartter. 1965. Evidence for a direct effect of parathyroid hormone on urinary acidification. Am. J. Physiol. 209: 643-650.

2. Ellsworth, R., and W. M. Nicholson. 1935. Further observations upon the changes in the electrolytes of the urine following injection of parathyroid extract. $J$. Clin. Invest. 14: 823-827.

3. Kleeman, C. R., and R. E. Cooke. 1951. The acute effects of parathyroid hormone on the metabolism of endogenous phosphate. J. Lab. Clin. Med. 38: 112-127.

4. Nordin, B. E. C. 1960. The effect of intravenous parathyroid extract on urinary $\mathrm{pH}$, bicarbonate and electrolyte excretion. Clin. Sci. (Oxf.). 19: 311-319.

5. Fourman, P., B. McConkey, and J. W. G. Smith. 1960. Defects of water reabsorption and of hydrogen-ion excretion by the renal tubules in hyperparathyroidism. Lancet. 1 : 619-623.

6. Agus, Z. S., L. B. Gardner, L. H. Beck, and M. Goldberg. 1973. Effects of parathyroid hormone on renal tubular reabsorption of calcium, sodium and phosphate. Am. J. Physiol. 224: 1143-1148.

7. Agus, Z. S., J. B. Puschett, D. Senesky, and M. Goldberg. 1971. Mode of action of parathyroid hormone and cyclic adenosine $3^{\prime}, 5^{\prime}$-monophosphate on renal tubular phosphate reabsorption in the dog. J. Clin. Invest. 50: 617-626.

8. Puschett, J. B., and M. Goldberg. 1969. The relationship between the renal handling of phosphate and bicarbonate in man. J. Lab. Clin. Med. 73: 956-969.

9. Counihan, T. B., B. M. Evans, and M. D. Milne. 1954 Observations on the pharmacology of the carbonic anhydrase inhibitor "Diamox." Clin. Sci. (Oxf.). 13: 583-598.

10. Fulop, M., and P. Brazeau. 1968. The phosphaturic effect of sodium bicarbonate and acetazolamide in dogs. J. Clin. Invest. $47:$ 983-991.

11. Malvin, R. L., and W. D. Lotspeich. 1956. Relation between tubular transport of inorganic phosphate and bicarbonate in the dog. Am. J. Physiol. 187: 51-56.

12. Rector, F. C., Jr., D. W. Seldin, A. D. Robert, Jr., and J. S. Smith. 1960. The role of plasma $\mathrm{CO}_{2}$ tension and carbonic anhydrase activity in the renal reabsorption of bicarbonate. J. Clin. Invest. 39: 1706-1721.

13. Rector, F. C., Jr., N. W. Carter, and D. W. Seldin. 1965. The mechanism of bicarbonate reabsorption in the proximal and distal tubules of the kidney. J. Clin. Invest. $44:$ 278-290.

14. Bernstein, B. A., and J. R. Clapp. 1968. Micropuncture study of bicarbonate reabsorption by the dog nephron. Am. J. Physiol. 214: 251-257.

15. Clapp, J. R., J. F. Watson, and R. W. Berliner. 1963. Effect of carbonic anhydrase inhibition on proximal tubular bicarbonate reabsorption. Am. J. Physiol. 205: 693-696.

16. Kunau, R. T., Jr. 1972. The influence of the carbonic anhydrase inhibitor, benzolamide (CL-11,366), on the reabsorption of chloride, sodium and bicarbonate in the proximal tubules of the rat. J. Clin. Invest. 51: 294-306. 
17. Beck, L. H., and M. Goldberg. 1973. Effects of acetazolamide and parathyroidectomy on renal transport of sodium, calcium, and phosphate. Am. J. Physiol. 224: 1136-1142.

18. Bank, N., H. S. Aynedjian, and S. W. Weinstein. 1974. A microperfusion study of phosphate reabsorption by the rat proximal tubule. J. Clin. Invest. 54: 1040-1048.

19. Maren, T. H. 1960. A simplified micromethod for the determination of carbonic anhydrase and its inhibitors. J. Pharmacol. Exp. Ther. 130: 26-29.

20. Maren, T. H., V. I. Ash, and E. M. Bailey, Jr. 1954. Carbonic anhydrase inhibition. II. A method for determination of carbonic anhydrase inhibitors, particularly of Diamox. Bull. Johns Hopkins Hosp. 95: 244255.

21. Davis, R. P. 1963. The measurement of carbonic anhydrase activity. In Methods of Biochemical Analysis. D. Glick, editor. Interscience Pubs, Inc., John Wiley and Sons, Inc., New York. 2: 307-327.

22. Beck, N., H. Singh, S. W. Reed, and B. B. Davis. 1974. Direct inhibitory effect of hypercalcemia on renal action of parathyroid hormone. J. Clin. Invest. 53: 717725.

23. Lowry, O. H., N. J. Rosebrough, A. L. Farr, and R. J. Randall. 1951. Protein measurement with the Folin phenol reagent. J. Biol. Chem. 193: 265-275.

24. Maren, T. H. 1967. Carbonic anhydrase: chemistry, physiology, and inhibition. Physiol. Rev. 47: 595-781.

25. Kernohan, J. C. 1966. A method for studying the kinetics of the inhibition of carbonic anhydrase by sulfonamides. Biochim. Biophys. Acta. 118: 405-412.

26. Maren, T. H., A. L. Parcell, and M. N. Malik. 1960. A kinetic analysis of carbonic anhydrase inhibition. J. Pharmacol. Exp. Ther. 130: 389-400.
27. Chase, L. R., and G. D. Aurbach. 1967. Parathyroid function and the renal excretion of $3^{\prime}, 5^{\prime}$-adenylic acid. Proc. Natl. Acad. Sci (U. S. A.). 58: 518-525.

28. Kurtzman, N. A., M. L. Karlinsky, and D. S. Sager. 1973. Effects of infusion of cyclic AMP and parathyroid hormone on renal bicarbonate reabsorption. Clin. Res. 21: 283. (Abstr.)

29. Beck, N. P., T. Kaneko, U. Zor. J. B. Field, and B. B. Davis. 1971. Effects of vasopressin and prostaglandin $\mathrm{E}_{1}$ on the adenyl cyclase-cyclic $3^{\prime}, 5^{\prime}$-adenosine monophosphate system of the renal medulla of the rat. $J$. Clin. Invest. 50 : 2461-2465.

30. Beck, N. P., S. W. Reed, H. V. Murdaugh, and B. B. Davis. 1972. Effects of catecholamines and their interaction with other hormones on cyclic $3^{\prime}, 5^{\prime}$-adenosine monophosphate of the kidney. J. Clin. Invest. 51: 939944.

31. Arnaud, C. D., H. S. Tasao, and T. Littledike. 1971. Radioimmunoassay of human parathyroid hormone in serum. J. Clin. Invest. 50: 21-34.

32. Marcus, R., and J. D. Aurbach. 1969. Bioassay of parathyroid hormone in vitro with a stable preparation of adenyl cyclase from rat kidney. Endocrinology. 85: 801-810.

33. Michelakis, A. M. 1970. Hormonal effects on cyclic AMP in a renal-cell suspension system. Proc. Soc. Exp. Biol. Med. 135 : 13-16.

34. Maren, T. H. 1963. The relation between enzyme inhibition and physiological response in the carbonic anhydrase system. J. Pharmacol. Exp. Ther. 139: 140 153.

35. Datta, P. K., and T. H. Shepard, II. 1959. Intracellular localization of carbonic anhydrase in rat liver and kidney tissues. Arch. Biochem. Biophys. 81: 124-129. 